Красинский Владислав Вячеславович доктор юридических наук, профессор Голицынского пограничного института, полковник

Professor of Golitsyno Military Institute, doctor of law, colonel Krasinsky Vladislav

Источник опубликования: Красинский В.В. Финансирование терроризма преступными организациями и осужденными исправительных учреждений // Современное право. 2016. № 4. С. 88-92.

\title{
Финансирование терроризма преступными организациями и осужденными исправительных учреждений
}

Терроризм как сложно организованная система постоянно трансформируется: происходит изменение сил, средств, форм и методов деятельности, совершенствование маскировки и управления, возникновение новых взаимосвязей.

К числу современных тенденций развития террористической деятельности, обусловленных трансформацией терроризма, относится сращивание террористического бандподполья с организованными преступными сообществами.

Данная тенденция проявляется в организации подконтрольных бандподполью преступных групп общеуголовного характера с целью финансирования террористической деятельности; создании бандформирований, полностью укомплектованных лицами, отбывшими наказание за совершение преступлений террористического характера ${ }^{1}$; формировании «тюремных» «джамаатов» в учреждениях исполнения наказаний, осуществляющих активную религиозно-экстремистскую обработку осужденных и сбор денежных средств в т.н. «бейтумал» («казну

${ }^{1}$ В 2012-2013 гг. в Республике Дагестан действовали 2 устойчивые бандгруппы («кизилюртовская» и «махачкалинская»), сформированные в местах лишения свободы. Большинство членов группы нижнекамских ваххабитов, задержанных в Татарстане в 2014 г., ранее отбывали наказание. В 2015 г. деятельность бандгруппы, состоявшей из бывших осужденных, была пресечена в Кабардино-Балкарской Республике. 
мусульман») $)^{1}$; использовании членами бандформирований связей в криминальной среде для приобретения поддельных документов, оружия, взрывчатых веществ, наркотиков и др. предметов, изъятых из гражданского оборота.

Актуальной проблемой противодействия терроризму становится нейтрализация угроз финансирования террористических структур и организации их противоправной деятельности из мест лишения свободы².

Регулярное и адекватное финансирование террористической деятельности является жизненно важной основой существования любой террористической организации ${ }^{3}$. Пресечение финансовой подпитки позволяет уменьшить масштабы и интенсивность террористических акций, снизить активность организационного ядра, функционеров и пособнических сетей бандподполья.

Анализ практики работы правоохранительных органов позволяет выделить ряд демаскирующих признаков, свидетельствующих о возможном

1 Данная проблема является актуальной и для зарубежных стран. По данным американских специалистов, количество мусульман - заключенных в ИУ США составляет более $15 \%$. Во Франции число заключенных - мусульман составляет от 50 до 80\%, в Италии и Испании - свыше 14\%. В исправительных учреждениях они группируются в изолированных от остальных осужденных общинах - «джамаатах». После отбывания наказания многие из радикальных исламистов компактно расселяются в закрытых анклавах.

2 В открытой научной литературе данная проблема практически не изучена. Имеющиеся публикации связаны, главным образом, с правовыми и историческими аспектами содержания заключенных, оперативно-розыскными мерами по обеспечению режима в исправительных учреждениях ФСИН России, вопросами радикализации тюремной среды. Агарков A.B. оперативно-розыскная деятельность в местах лишения свободы: правовые и исторические проблемы: Дис. ... канд. юрид. наук. Владимир, 2006; Федореев П.Р. Отрицательно характеризующиеся осужденные в местах лишения свободы Дис. ... канд. юрид. наук. Рязань, 2005; Злобин B.C. Оперативно-розыскные меры по обеспечению режима в исправительных учреждениях ФСИН России. Дис. ... канд. юрид. наук. Владимир, 2010; Усманов И.М. Исламская радикализация осужденных к лишению свободы - миф или реальность? // Право и безопасность. 2014. № 2; Меркурьев В.В., Агапов П.В. Проблемы пресечения и предупреждения экстремистской деятельности в исправительных учреждениях ФСИН России // Право и безопасность. 2014. № 2.

3 Под финансированием террористической деятельности понимается предоставление или сбор денежных средств либо оказание финансовых услуг для организации, подготовки или совершения преступлений террористического характера либо для обеспечения террористических организаций, автономных террористических ячеек, лагерей подготовки боевиков или террористов-одиночек. 
финансировании и ресурсном обеспечении криминальными структурами террористической деятельности. К их числу относятся:

- формирование организованной преступной группы на этнической основе;

- создание и деятельность предприятий и бизнес-структур, аффилированных с организованной преступной группой;

- использование участниками преступных групп и их связями из числа представителей национальных землячеств и диаспор альтернативных систем денежных переводов («хавала»);

- отбывание наказания лицами, осужденными за преступления террористического характера и экстремистской направленности, в т.н. «черных» зонах, где ими организуются и поддерживаются неконтролируемые администрацией исправительных учреждений каналы связи ;

- наличие устойчивых конспиративных связей между криминальными структурами, действующими на «воле», с «тюремными джамаатами» и «братьями» в исправительных учреждениях ${ }^{2}$.

Организованные преступные группы, сформированные на этнической основе, как правило, тесно связаны с террористическими и экстремистскими структурами.

1 «Черными» зонами на криминальном жаргоне называют исправительные учреждения, находящиеся под «воровским» влиянием, т.е. под контролем организованных преступных групп, действующих в районе их дислокации. Отбывающие там наказание осужденные могут за денежное вознаграждение облегчить свои условия содержания. «Красные» («режимные») зоны контролируются администрациями исправительных учреждений.

${ }^{2}$ Взаимодействие «воли» и «зоны», как правило, проявляется в различных формах: привлечение членов общественно-наблюдательных комиссий для воздействия на администрацию исправительных учреждений; организация массовых однотипных жалоб в прокуратуру на условия содержания с целью парализации работы колонии; инициирование массовых беспорядков («вспышек») для дезорганизации исправительного учреждения и улучшения режима отбывания наказания; организация побегов из мест лишения свободы; снабжение колоний алкогольными напитками, наркотическими веществами, психотропными средствами, мобильными телефонами и иными запрещенными предметами; перечисление определенной доли доходов с «игры», теневого и легального бизнеса и др. 
Часть общеуголовных преступных формирований, прикрываясь лозунгами «джихада», совершает грабежи и разбойные нападения, занимается вымогательством денежных средств у чиновников и предпринимателей, совершает иные преступления корыстного характера для обеспечения своей деятельности. Традиционная в прошлом для СевероКавказского и Южного федеральных округов практика «заряжания флэшек» с вымогательством денег от имени «муджахидов» и «амиров» бандподполья получила распространение в других регионах Российской Федерации, в местах компактного проживания выходцев из Северного Кавказа ${ }^{1}$.

В ряде случаев под боевые «джамааты» создаются специальные преступные группы, основной задачей которых является их финансирование и ресурсное обеспечение.

С другой стороны, этнические криминальные группировки нередко трансформируются в религиозно-экстремистские ячейки, начинающие «идейную борьбу» с органами власти и управления. В ходе расследования уголовных дел с квалифицирующими признаками составов «Кража», «Разбой», «Мошенничество» и др. правоохранительными органами неоднократно выявлялись факты организации, подготовки или совершения преступлений участниками «джамаатов», которые осуществляли сбор денег или оказывали финансовые услуги для пропаганды терроризма, рекрутирования в ряды международных террористических организаций, снабжения членов бандподполья.

Этнические организованные преступные группы, как правило, оказывают значительную поддержку террористам. При этом активно используются платежные системы, переводы электронной валюты, безналичные расчеты в небанковской сфере и другие финансовые инструменты.

1 Примером могут служить Ханты-Мансийский автономный округ, Тюменская область, Магаданская область, Приморский край и др. субъекты Российской Федерации, где проживают выходцы из Дагестана, Чечни и Ингушетии. 
Этнические криминальные структуры задействуют возможности альтернативных систем денежных переводов. Для осуществления перевода по такой неформальной платежной системе следует обратиться к содержателю пункта «хавала» (действуют под прикрытием туристических фирм, пунктов обмена валюты, магазинов), передать необходимую сумму и назвать получателя. Адресат перевода получает денежные средства в необходимой ему валюте (за вычетом процента за услуги по переправке). После проведения переводов осуществляется взаимозачет. Данные о клиентах, получателях и переводах фиксируются в т.н. «бухгалтерии» в кодированной форме. Данные обстоятельства, являющиеся демаскирующими элементами системы «хавала», используются правоохранительными органами при документировании и доказывании преступной деятельности, связанной с финансированием терроризма.

Денежные средства, добытые преступным путем, легализуются с помощью аффилированных с криминальными структурами организаций. Как правило, эти организации связаны со строительной, торговой или кредитнобанковской сферами. Организованные преступные группы стремятся установить контроль над представляющими интерес хозяйствующими субъектами и бюджетообразующими предприятиями путем постепенного выдавливания неугодных учредителей и директоров.

Обслуживающие криминальные структуры частные охранные предприятия используются для «крышевания» мелких и средних предпринимателей.

В ходе работы по выявлению, предупреждению, пресечению и раскрытию финансирования террористической деятельности следует учитывать наличие устойчивых конспиративных связей между криминальными структурами, действующими на «воле», с «тюремными джамаатами» и «братьями» в исправительных учреждениях.

Особенности режима содержания осужденных в «черных» зонах (возможности проноса и использования сотовых телефонов, «кони», 
«дороги» и др.) позволяют спецконтингенту организовывать неконтролируемые администрацией исправительных учреждений каналы связи с «волей» (как правило, по линии связи «осужденный - пособник»). Коррумпированные должностные лица уголовно-исполнительной системы получают и передают осужденным по террористическим и экстремистским статьям денежные средства, приобретают и доставляют в места лишения свободы мобильные телефоны.

Правоохранительными органами фиксировались факты организации устойчивой связи и попытки координации террористической деятельности бандподполья со стороны лиц, отбывающих наказание в местах лишения свободы («черных» зонах). Осужденные за совершение преступлений террористического характера, пользуясь мобильными телефонами с выходом в интернет, нередко сами организуют финансирование террористической деятельности, создавая и используя «исламские» сайты и закрытые группы в социальных сетях.

Как представляется, изучение актуальных вопросов противодействия финансированию терроризма организованными преступными группами и спецконтингентом исправительных учреждений необходимо проводить с учетом ряда оговорок.

Во-первых, перечисленные в данной статье признаки, свидетельствующие о возможном финансировании и ресурсном обеспечении террористической деятельности, не являются исчерпывающими.

Во-вторых, изменение тактики преступной деятельности и совершенствование представителями криминалитета, a также членами террористических структур мер конспирации при организации и сопровождении финансирования террористической деятельности вызывают появление новых демаскирующих признаков, своего рода индикаторов для правоохранительных органов.

В-третьих, указанные признаки зависят от особенностей конкретного региона (инвестиционная и миграционная привлекательность, уровень 
развития финансово-кредитной системы, состояние межнациональных и межконфессиональных отношений, криминогенная ситуация и др.), профессионализма членов криминальных структур и террористических ячеек, степени коррупционной пораженности органов власти и управления, эффективности правоохранительных органов и др. факторов.

Результаты аналитической работы по оценке демаскирующих признаков, свидетельствующих о возможном финансировании террористической деятельности организованными преступными группами и спецконтингентом исправительных учреждений, носят сигнальный характер, поскольку позволяют смоделировать наиболее вероятные каналы и источники финансирования, и могут служить основанием для проверки причастности установленных лиц к террористической деятельности бандподполья или оказанию пособнической помощи.

Учитывая специфику обстановки на линии противодействия финансированию терроризма, в качестве приоритетных задач правоохранительных органов по пресечению финансовой подпитки террористической деятельности со стороны криминальных структур можно выделить:

- разработку этнических преступных групп и членов конспиративных ячеек религиозных общин («джамаатов») из числа выходцев из мусульманских республик Российской Федерации и приграничных государств ЦАР ${ }^{1}$;

- контроль за финансово-хозяйственной деятельностью предприятий и бизнес-структур, аффилированных с этническими организованными преступными группами; выявление источников и каналов финансирования этими структурами террористического бандподполья;

- выявление и пресечение каналов связи, финансирования и материально-технического обеспечения лиц, осужденных за совершение преступлений террористического характера и экстремистской

1 Особое внимание при разработке этнических преступных групп и джамаатов необходимо уделять выявлению как легальных, так и нелегальных источников доходов. 
направленности, с находящимися на свободе членами террористического бандподполья;

- выявление и пресечение попыток финансирования террористических ячеек и боевиков - одиночек в Российской Федерации из-за рубежа ${ }^{1}$;

- выявление и разработку пособников, осуществляющих финансовое, ресурсное и материально-техническое обеспечение этнических организованных преступных групп и бандформирований;

- выявление и пресечение попыток использования участниками преступных групп и их связями из числа представителей национальных землячеств и диаспор альтернативных систем денежных переводов для финансирования бандподполья.

Как представляется, последовательное решение этих задач в рамках противодействия финансирования террористической деятельности позволит нормализовать криминогенную обстановку и создаст необходимые условия для ограничения и прекращения деятельности на территории Российской Федерации организационных структур, законспирированных террористических ячеек и пособнических сетей террористических организаций.

Важнейшими предпосылками для сокращения интенсивности и географических масштабов террористической деятельности остаются пресечение рекрутирования новых боевиков - террористов (в том числе из числа осужденных) и нарушение воспроизводства идеологической, финансовой и ресурсной базы террористических структур как на «воле», так и в местах лишения свободы.

1 Интерес представляют организации, учрежденные гражданами иностранных государств, поддерживающих экстремистские движения (Турции, Катара, Саудовской Аравии и др.); юридические лица, обоснованно подозреваемые в оказании помощи бандформированиям в Северо-Кавказском регионе; граждане, осуществляющие перевозку крупных сумм денежных средств через государственную границу. 